\title{
$\mathrm{CPU}$ 클러스터 구축 및 3차원 공간분할 병렬 FDTD 알고리즘 구현
}

\section{Construction of a CPU Cluster and Implementation of a 3-D Domain Decomposition Parallel FDTD Algorithm}

\author{
박성민 · 추광욱* · 주세훈 ${ }^{\star} \cdot$ 박윤미 ${ }^{*}$. 김기백* · 정경영
}

Sungmin Park $\cdot$ Kwang-Uk Chu* $\cdot$ Saehoon Ju* $\cdot$ Yoon-Mi Park* $\cdot$ Ki-Baek Kim* $\cdot$ Kyung-Young Jung

요 약

본 연구에서는 빠르게 전자파 해석을 수행할 수 있는 병렬 유한차분 시간영역(Finite-Difference Time-Domain: FDTD) 알고리즘을 구현하기 위하여 CPU 클러스터를 구축하였다. 병렬 FDTD 알고리즘은 단일 프로세서를 이용한 FDTD 알고 리즘에 비해 해석 시간을 크게 줄일 수 있으며, 전기적으로 매우 큰 구조물에 대한 전자파 해석도 가능하다. 본 연구팀에 서는 CPU 클러스터 기반의 병렬 FDTD 알고리즘에서 요구되는 프로세스 간의 통신을 위해 MPI(Message Passing Interface) 라이브러리를 이용하였으며, 3 차원 공간분할을 적용하여 프로세스 간의 통신 시간을 최소화하였다. 단일 프로 세서를 이용한 FDTD 알고리즘 대비 CPU 클러스터 기반의 병렬 FDTD 알고리즘의 계산속도 향상도를 기본 모드와 하이 퍼 모드에서 분석하였으며, 전기적으로 매우 큰 콘크리트 구조물의 전자파 해석을 하였다.

\section{Abstract}

In this work, we construct a CPU cluster to implement a parallel finite-difference time domain(FDTD) algorithm for fast electromagnetic analyses. This parallel FDTD algorithm can reduce the computational time significantly and also analyze electrically larger structures, compared to a single FDTD counterpart. The parallel FDTD algorithm needs communication between neighboring processors, which is performed by the MPI(Message Passing Interface) library and a 3-D domain decomposition is employed to decrease the communication time between neighboring processors. Compared to a single-processor FDTD, the speed up factor of a-CPU-cluster-based parallel FDTD algorithm is investigated for the normal mode and the hypermode and finally analyze an electrically large concrete structure by the developed parallel algorithm.

Key words: FDTD, MPI, Parallel Processing, 3-D Domain Decomposition

\section{I. 서 론}

오늘날의 수치해석 기법은 과학 기술 전반에 걸쳐 중 요한 역할을 하고 있다. 여러 전자파 해석 기법 중 유한차
분 시간 영역(Finite-Difference Time-Domain: FDTD)법 ${ }^{[1]}$ 은 한 번의 시뮬레이션으로 광대역 주파수 특성을 해석할 수 있으며, 복잡한 물질 및 구조를 쉽게 해석할 수 있기 때문에 널리 사용되고 있다[2] [5]. 하지만 해석의 규모가

「이 논문은 2012년도 정부(미래창조과학부)의 재원으로 한국연구재단의 지원을 받아 수행된 기초연구사업임(2012R1A1A1015159).」

「본 연구는 ETRI 부설연구소 위탁과제의 연구 결과로 수행되었음.

한양대학교 전자컴퓨터통신공학과(Department of Electronics Computer Engineering, Hanyang University)

*ETRI 부설연구소 (Attached Institute of ETRI)

- Manuscript received December 6, 2013 ; Revised March 4, 2014 ; Accepted March 5, 2014. (ID No. 20131206-09S)

· Corresponding Author: Kyung-Young Jung (e-mail: kyjung3@hanyang.ac.kr) 
큰 구조일 경우, 해석에 소요되는 시간이 매우 많거나, 계 산량이 많아 단일 컴퓨터의 한정된 메모리 문제로 인하 여 해석이 불가능할 수 있다. 이러한 문제를 해결하기 위 해 다중 컴퓨터 환경을 이용하는 공간 분할 병렬처리 방 법이 소개되었다. FDTD 기법은 공간을 해석할 때, $\mathrm{E}$ 필 드와 $\mathrm{H}$ 필드의 정보 만을 주고받으며 행렬 계산을 하지 않는 양함수(explicit) 수치해석 기법이기 때문에, 행렬계 산이 필요한 음함수(implicit) 수치해석 기법인 $\mathrm{FEM}$ 과 $\mathrm{MOM}$ 기법에 비하여 공간 분할 병렬처리 기법을 용이하게 적 용할 수 있다. 공간 분할 병렬처리는 해석공간을 분할하 여 여러 대의 컴퓨터에서 각각의 계산을 수행하고, 계산 된 정보를 순차적으로 다시 취합하는 방법이며, 시스템적 으로 단일 $\mathrm{CPU}$ 만을 이용하여 해석하는 경우보다 $\mathrm{CPU}$ 개 수와 메모리가 늘어난 것이므로 해석 공간의 크기뿐만 아니라, 해석 시간도 획기적으로 빨라질 수 있다. 이러한 $\mathrm{CPU}$ 클러스터를 기반으로 하여 공간 분할 병렬처리 FD$\mathrm{TD}$ 를 이용한 크고 복잡한 구조물의 고속 전자파 특성 해 석 연구가 국내에서는 거의 이루어지고 있지 않으나, 국 외에서는 2000년대부터 선진국을 중심으로 지속적으로 연구되고 있으며, 클러스터를 구성하는 $\mathrm{CPU}$ 개수 등에 따른 효율에 대한 연구도 이루어지고 있다[6]- [8].

본 논문에서는 본 연구팀에서 구축한 $\mathrm{CPU}$ 클러스터 하드웨어에 대한 시스템 구성을 설명하고, 공간 분할 병 렬처리 방법에서 프로세서 간의 통신을 위해 MPI(Message Passing Interface) 라이브러리를 적용한 1차원 및 3차 원 FDTD 기법에 대하여 기술하였다. 또한, 프로세서 간 의 통신 시간을 최소화시키기 위해 이용한 3 차원 공간 분 할에 대하여 설명하고, 구현된 CPU 클러스터 기반의 병 렬 FDTD 알고리즘의 성능이 하이퍼 모드의 구동 여부에 따라 어떻게 변하는지를 확인하기 위하여 단일 프로세서 와 계산 성능을 비교 분석하였고, 단일 프로세서로는 계 산할 수 없는 전기적으로 큰 콘크리트 구조물에서의 전 자파 해석을 수행하였다.

\section{II. 하드웨어 구축}

공간 분할 병렬처리 FDTD 기법을 구현하기 위하여 본 연구팀에서는 그림 1 과 같이 $\mathrm{CPU}$ 기반의 클러스터를 구

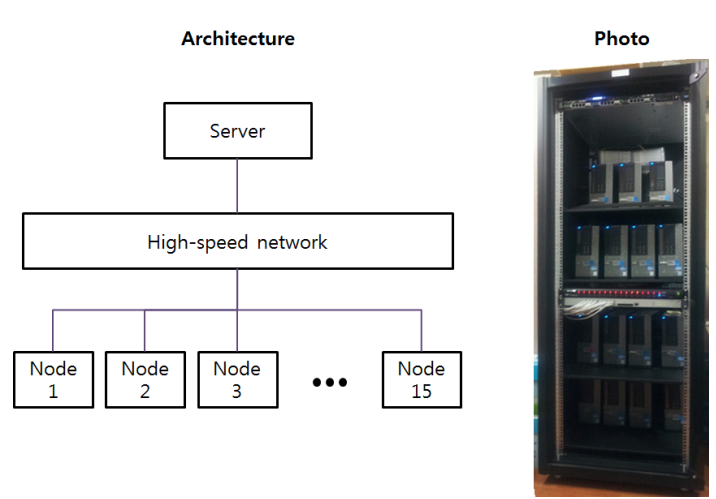

그림 1. 한양대학교 응용전파기술연구실의 $\mathrm{CPU}$ 클러스터 Fig. 1. CPU cluster at HYU AETL.

성하였다. 서버는 Dell사의 PowerEdge R310을 사용하고 있으며, 리눅스 기반의 CentOS 5.8을 OS로 사용하고 있 다. 노드는 15 개로 구성되어 있으며, 각 노드들은 Dell사 의 OptiPlex 990SFF를 사용하고 있다. 각 노드는 한 개의 물리적 코어를 두 개의 논리적 코어로 동작하게 하는 하 이퍼 스레딩(hyper-threading) 기술을 지원하는 Intel(R) Co$\mathrm{re}(\mathrm{TM})$ i7-2600 쿼드코어 프로세서를 탑재하여 총 120 $(=4 \times 2 \times 15)$ 개의 코어를 보유하고 있으며, $16 \mathrm{~GB}$ Non-ECC DDR3 $1,333 \mathrm{MHz}$ SDRAM 메모리로 구성되어 총 240 (=16×15) $\mathrm{GB}$ 의 메모리를 지원하며, 고성능 컴퓨터 모니 터링 시스템인 Ganglia로 본 연구팀에서 구축한 CPU 클 러스터를 모니터링 한다. 서버와 각 노드들의 사이는 1,000 Mbps CAT.6 다이렉트 랜 케이블로 연결하였다.

\section{MPI-FDTD}

$\mathrm{CPU}$ 기반의 병렬 FDTD 알고리즘을 구현하기 위해서 는 필수적으로 다중 프로세서 환경에서 각 프로세서 간 의 데이터 통신이 요구되며, 본 연구팀에서는 이를 위해 MPI 라이브러리 ${ }^{[9]}$ 를 적용하였다. 본 절에서는 데이터 통 신을 설명하기 위해 1차원 MPI-FDTD 알고리즘에 대하여 간단히 설명하고, 이를 바탕으로 3차원 MPI-FDTD 알고 리즘에 대하여 기술하였다. 또한, 3 차원 MPI-FDTD 구현 시 발생하는 문제점을 분석하고, 그 해결방안을 설명하였다.

\section{3-1 1차원 MPI-FDTD}

그림 2는 1차원 MPI-FDTD에서의 데이터 통신 과정을 
$\begin{array}{llllllllll}\text { Ex1 } & \text { Ex2 } & \text { Ex3 } & \text { Ex4 } & \text { Ex5 } & \text { Ex6 } & \text { Ex7 } & \text { Ex8 } & \text { Ex9 } & \text { Ex10 }\end{array}$

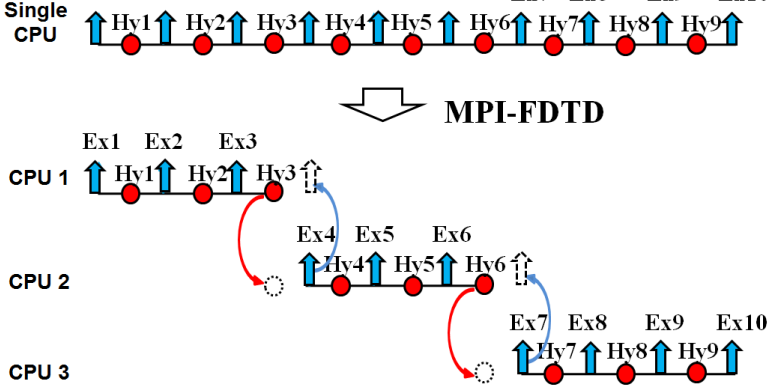

그림 2. 1차원 데이터 통신

Fig. 2. 1-D data communication.

도시한 것이다. 아주 간단한 예로, $9 \mathrm{Cell}$ 의 공간을 해석 하기 위하여 3 개의 CPU로 해석공간을 $3 \mathrm{Cell}$ 씩 나누었다 고 가정하자.

$\mathrm{CPU} 1$ 에는 각각 3 개의 $\mathrm{Ex}$ 와 $\mathrm{Hy}, \mathrm{CPU} 2$ 에는 각각 3 개 의 $\mathrm{Ex}$ 와 $\mathrm{Hy}, \mathrm{CPU} 3$ 에는 4 개의 $\mathrm{Ex}$ 와 3 개의 $\mathrm{Hy}$ 가 존재한 다. 1차원으로 $\mathrm{Ex}$ 를 업데이트하기 위해서는 좌우 양쪽의 $\mathrm{Hy}$ 가 필요하고, $\mathrm{Hy}$ 를 업데이트하기 위해서도 좌우 양쪽 의 $\mathrm{Ex}$ 가 필요한데, $\mathrm{CPU} 1$ 에서 $\mathrm{Hy} 3$ 를 업데이트하기 위해 서는 $\mathrm{Ex} 3$ 과 $\mathrm{Ex} 4$ 가 필요하다. 하지만 $\mathrm{CPU} 1$ 에서는 $\mathrm{Ex} 4$ 가 존재하지 않기 때문에 $\mathrm{CPU}$ 2에서 가져와 계산하여야 한 다. 한편, $\mathrm{CPU}$ 2에서 $\mathrm{Ex} 4$ 를 업데이트하기 위해서는 $\mathrm{Hy} 3$ 과 $\mathrm{Hy} 4$ 가 필요한데, $\mathrm{CPU}$ 2에는 $\mathrm{Hy} 3$ 이 존재하지 않기 때 문에 $\mathrm{CPU} 1$ 에서 가져와 계산하여야 한다. 이렇게 $\mathrm{Ex}$ 와 $\mathrm{Hy}$ 가 각 $\mathrm{CPU}$ 사이에서 송 - 수신하는 것을 데이터 통신 이라 말하며, 이와 같은 데이터 통신은 병렬 FDTD 알고 리즘에서 꼭 필요하다. 공간 분할 병렬처리를 위한 데이 터간의 통신은 MPI 라이브러리를 이용하여 제어하는데, $\mathrm{MPI}$ 를 이용한 간단한 MPI-FDTD 코드는 아래와 같다.

$$
\begin{aligned}
& \text { \#include <mpi.h> } \\
& \text { MPI_Init } \\
& \text { MPI_Comm_Size } \\
& \text { MPI_Comm_Rank } \\
& \text { Setup_Parameter } \\
& \text { for n=1:nstep } \\
& \quad \text { Update_E_field } \\
& \quad \text { MPI_Isend }
\end{aligned}
$$

\author{
MPI_Irecv \\ MPI_Wait \\ MPI_Barrier \\ Update_H_field \\ MPI_Isend \\ MPI_Irecv \\ MPI_Wait \\ MPI_Barrier \\ end
}

Post_Processing

MPI Finalize

MPI 함수들을 사용하기 위해서는 코드의 처음에 MPI 헤더 파일을 포함시켜야 한다. MPI 헤더 파일은 MPI 서 브루틴과 함수들의 프로토 타입을 포함하고 있으며, 매크 로들의 정의와 MPI 관련 인수들과 데이터 타입들을 정의 하고 있다. 헤더 파일을 설정한 뒤에는 MPI_Init 함수를 사용하여 MPI를 초기화 한다. MPI Init는 MPI 함수를 이 용한 코드 상에서 가장 처음에 나오는 함수로 $\mathrm{MPI}$ 를 초 기화 하며, 초기화 하는데 문제가 생기는 경우 오류 코드 를 되돌려준다. MPI의 초기화 이후에는 MPI_Comm_Size 함수를 사용하여 $\mathrm{CPU}$ 의 개수를 설정한다. 이 과정은 공 간 분할 병렬처리를 하기 위하여 구동되는 가용 $\mathrm{CPU}$ 의 총 개수를 선언하고, 그 값을 되돌려주는 작업이다. 가용 CPU의 개수를 설정한 후에는 MPI_Comm_Rank 함수를 사용하여 고유번호를 부여한다. 이 작업은 가용 $\mathrm{CPU}$ 들에 게 각각의 고유번호를 부여하여 사용자가 원하는 계산을 정해진 $\mathrm{CPU}$ 에서 계산할 수 있도록 돕는 함수이다. 만약 $n$ 개의 $\mathrm{CPU}$ 가 설정되었다면, 각각의 $\mathrm{CPU}$ 에는 0 부터 $n-$ 1 까지 번호가 할당된다. 이렇게 MPI의 시작을 위한 함수 들이 구동된 후, 해석 공간의 크기와 간격, 시간 간격 등 의 변수 설정을 하고, $\mathrm{E}$ 필드와 $\mathrm{H}$ 필드를 업데이트하기 위한 for 루프문을 시작한다. $\mathrm{E}$ 필드를 업데이트 하고, MPI_Isend 함수를 이용하여 $\mathrm{E}$ 필드를 다른 $\mathrm{CPU}$ 로 송신 하고, 마찬가지로 MPI Irecv 함수를 이용하여 E 필드의 정보를 수신한다. MPI_Wait 함수와 MPI_Barrier 함수를 이용하여 모든 $\mathrm{CPU}$ 에서 $\mathrm{E}$ 필드의 송수신이 완벽히 끝난 이후에 $\mathrm{H}$ 필드 업데이트 과정을 진행할 수 있도록 돕는 


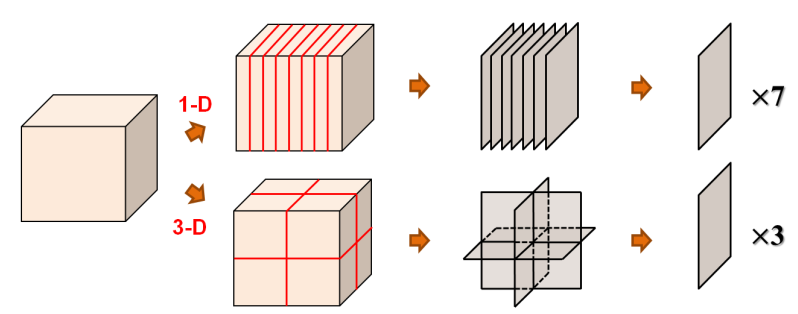

그림 3. 1차원 및 3 차원 공간분할

Fig. 3. 1-D and 3-D domain decompositions.

다. $\mathrm{H}$ 필드의 업데이트도 $\mathrm{E}$ 필드와 동일한 순서로 진행된 다. 최종적으로 nstep에 해당되는 횟수만큼 for 루프문을 반복하게 되고, for 루프문이 끝나면 후처리 작업을 거친 후 MPI_Finalize 함수를 이용하여 MPI를 끝낸다.

\section{3-2 3차원 MPI-FDTD}

다음으로 3-1의 1차원 MPI-FDTD를 기반으로 하여 3차 원 MPI-FDTD에 대하여 기술하겠다.

그림 3에서 확인할 수 있듯이 해석공간을 8 개로 분할 한다고 가정하면 1 차원으로 나눌 때 데이터 통신량이 7 개의 기준면적이 필요하지만, 3 차원으로 나누게 될 경우, 3 개의 기준면적만 송 - 수신하게 되므로 통신에 사용되는 시간을 기준으로 고려하면 3차원으로 공간을 분할하여 해석공간을 계산하는 것이 유리하다. 3 차원의 MPI-FDTD 는 1차원 MPI-FDTD와 달리 $\mathrm{Ex}, \mathrm{Ey}, \mathrm{Ez}, \mathrm{Hx}, \mathrm{Hy}, \mathrm{Hz}$ 의 6 개 의 필드 성분에 대한 업데이트가 이루어져야 한다.

그림 4 와 같이 3 차원 공간분할을 사용하는 3 차원 MPIFDTD는 MPI Isend와 MPI Irecv 함수를 이용하여 송수신 이 이루어질 때 2 차원 배열의 필드 정보가 필요하다. 예
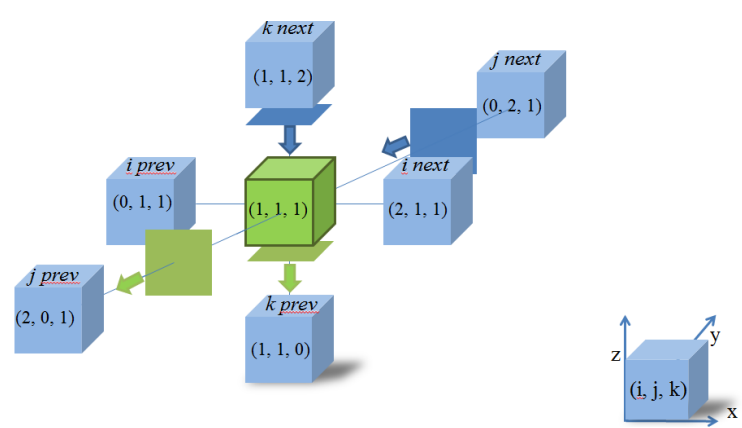

그림 4. Ex 필드의 데이터 교환

Fig. 4. Data exchange of Ex field.

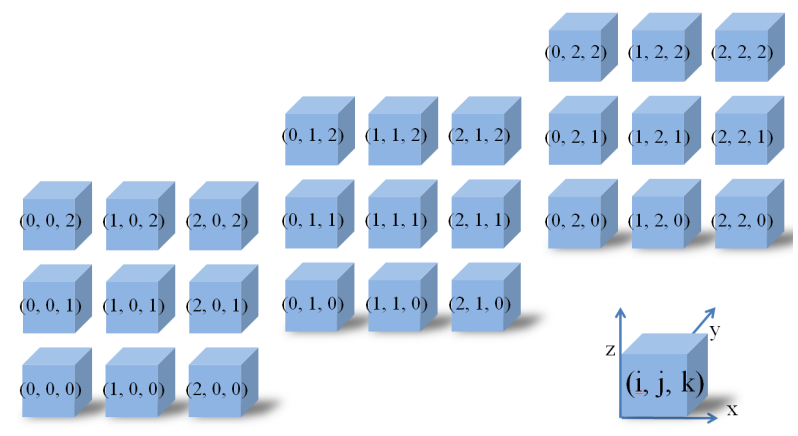

그림 5. 3차원 공간분할의 테이블 구성도

Fig. 5. Table of 3-D domain decomposition.

를 들어, $\mathrm{Ex}$ 성분은 2차원 필드 정보를 $\mathrm{j} \mathrm{prev,} \mathrm{k}$ prev로 송신하고, j next, k next에서 수신하며, Ey 성분는 2차원 필드 정보를 i prev, $\mathrm{k}$ prev로 송신하고, i next, k next 로부 터 수신한다. 마지막으로 $\mathrm{Ez}$ 성분은 2차원 필드 정보를 $\mathrm{i}$ prev, j prev로 송신하고, i next, j next로부터 수신한다. 한 편, $\mathrm{Hx}$ 성분은 2차원 필드 정보를 $\mathrm{j}$ next, $\mathrm{k}$ next 로 송신하 고, j prev, k prev에서 수신하며, Hy 성분은 2차원 필드 정 보를 i next, $\mathrm{k}$ next로 송신하고, i prev, k prev로부터 수신 한다. 마지막으로 $\mathrm{Hz}$ 성분은 2차원 필드 정보를 $\mathrm{i}$ next, $\mathrm{j}$ next로 송신하고, i prev, j prev로부터 수신한다. 그림 2와 같은 1 차원 데이터 통신에서 알 수 있듯이 $\mathrm{E}$ 필드와 $\mathrm{H}$ 필 드의 개수가 상이한 점을 고려하여, 3 차원의 MPI-FDTD 에서도 각각의 $\mathrm{CPU}$ 에 할당된 정확한 $\mathrm{E}$ 필드와 $\mathrm{H}$ 필드의 모델링이 필요하다.

그림 5 는 해석공간을 $x y z$ 축으로 $3 \times 3 \times 3$ 으로 나눈 3 차 원 공간분할을 도시한 그림이다.

그림 5의 각각의 테이블(CPU의 고유번호)들은 MPI Isend와 MPI_Irecv 함수를 이용하여 인접한 테이블과 통 신을 하게 된다. 예를 들어 $(1,1,1)$ 인 테이블은 각 이웃 테이블인 $(1,0,1),(1,2,1),(1,1,2),(1,1,0),(0,1,1)$, $(2,1,1)$ 과 정보를 주고받는다. 하지만 $i=0,2$ 인 테이블과 $j=0,2$ 인 테이블, 그리고 $k=0,2$ 인 테이블은 최 외곽에 위 치하고 있기 때문에, 하나 이상의 이웃 테이블이 존재하 지 않으므로 데이터 통신을 할 수 없는 구조적인 문제가 발생하게 된다. 이와 같은 문제를 해결하기 위하여 테이 블의 위치마다 각각의 업데이트 식을 모두 다르게 설정 하여야 하는데, 이 방법은 코드도 복잡해져 비효율적인 
해결 방법이라고 볼 수 있다. 이를 해결하기 위하여 해석 공간에 해당하는 테이블들을 감싸는 더미 테이블을 만들 어 MPI_Procs_Null ${ }^{[10]}$ 을 선언하였다. MPI_Procs_Null을 선 언한 더미 테이블이 다른 테이블과 통신을 할 경우, 실제 로 통신이 이루어지지 않지만 에러가 일어나지 않는다. 더미 테이블을 이용함으로써 경계에 존재하는 테이블들 사이의 데이터 송수신 간에 생길 문제를 해결할 수 있는 MPI 공간 분할의 경계조건을 설정하였다고 볼 수 있다.

\section{Numerical Example}

$\mathrm{CPU}$ 클러스터 기반의 MPI 라이브러리와 3차원 공간 분할을 적용한 병렬 FDTD 알고리즘을 이용하여 계산하 였을 때, $\mathrm{CPU}($ 코어)수에 따른 계산 속도를 확인하기 위해 서 단일 프로세서의 계산 속도를 기준으로 다중 프로세 서에서 사용하는 $\mathrm{CPU}$ 의 수를 각각 $8,16,24,32,40,48$, 60 개로 계산시간을 측정하였다. 또한, 항상 하이퍼스레딩 기술을 이용하도록 하여 물리적 $\mathrm{CPU}$ 개수보다 2배 많은 논리적 $\mathrm{CPU}$ 의 개수를 사용하는 하이퍼 모드를 가동하여 $8,16,24,32,40,48,60,72,88,104,120$ 개의 $\mathrm{CPU}$ 를 구동 하여 계산시간을 측정하였다. 해석 공간은 $200 \times 200 \times 200$ (cell) 크기의 자유공간으로 이루어져 있으며, $10 \times 10 \times 10$ (cell) 크기의 PML이 자유공간 각 면의 외부를 감싸고 있 다. 시뮬레이션 수행을 위해 공간 간격은 $\Delta x=\Delta y=\Delta z=5$ $\mathrm{mm}$ 로 선택하였으며, 시간은 $\Delta t=9.526279 \mathrm{ps,} \mathrm{nstep=1000}$ 으로 설정하였다. 입사하는 전자파는 미분형 가우시안 펄 스인 포인트 소스를 해석 공간의 정 가운데로 여기시켰 다. 다중 프로세서 FDTD 코드의 성능을 비교하기 위하여 동일한 조건의 단일 프로세서 FDTD 코드도 함께 시뮬레 이션을 하였으며, 각 조건에 대한 계산 시간을 도시하면 그림 6 과 같다.

그림 6에서 단일 프로세서 조건일 때 시뮬레이션의 계 산 시간은 2,795초가 소요되었으며, 단일 프로세서 조건 에서 걸린 시간을 기준으로 다중 프로세서 조건일 때 시 뮬레이션의 계산 시간을 계산속도 향상도로 나타내었다. 그림에서 보는 바와 같이 기본 모드에서 $\mathrm{CPU}$ 의 개수가 60 개일 때의 계산 시간은 54 초로 단일 프로세서 조건일 때보다 약 51.76배로 $\mathrm{CPU}$ 의 수가 증가할수록 계산속도 향상도가 증가함을 알 수 있다. 하지만, $\mathrm{CPU}$ 의 수가 많아

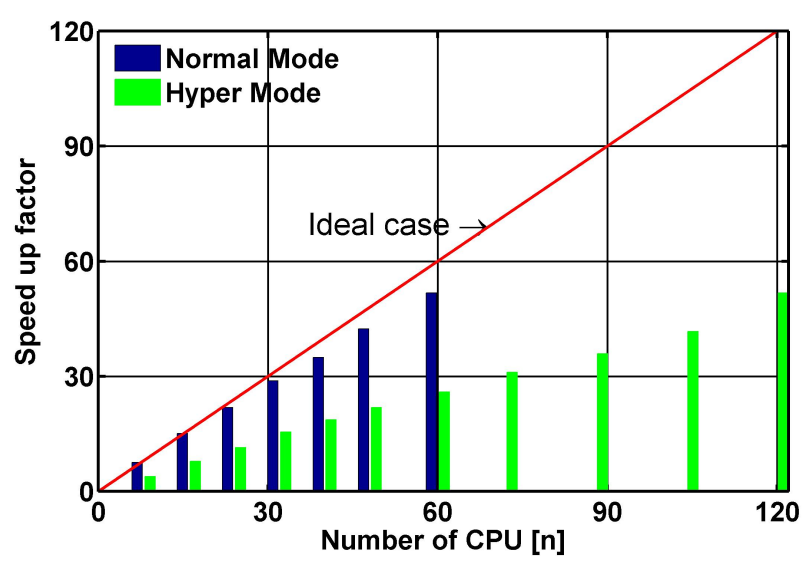

그림 6. $\mathrm{CPU}$ 수에 대한 계산 속도의 증가

Fig. 6. Speed up factor versus CPU numbers.

질수록 이상적인 계산시간 향상도보다 조금씩 떨어지는 것을 확인할 수 있었다. 한편, 하이퍼 모드를 동작시켜 동 일한 실험을 진행한 결과, 기본 모드의 계산시간 향상도 보다 두 배 정도 성능이 떨어짐을 확인할 수 있다. 이는 하이퍼 모드에서의 $\mathrm{CPU}$ 증가는 논리적인 $\mathrm{CPU}$ 의 수를 증 가시키지만, 계산 속도에는 영향을 주지 않음을 알 수 있 으며, 따라서 물리적인 $\mathrm{CPU}$ 의 증가 만이 계산 속도에 영 향을 준다는 점을 알 수 있다. 단일 프로세서를 이용하여 시뮬레이션한 결과와 다중 프로세서를 이용하여 시뮬레 이션한 결과의 정확도를 비교하기 위하여 포인트 소스를 여기시킨 지점에서 $\mathrm{x}, \mathrm{y}, \mathrm{z}$ 축으로 각각 5 cell 만큼 떨어진 곳의 $\mathrm{Ez}$ 값을 비교하였다. $200 \times 200 \times 200$ (cell) 크기의 공간 에서 단일 프로세서로 모의실험한 결과, 60 개의 $\mathrm{CPU}$ 로 모의실험한 결과, 그리고 $1,000 \times 1,000 \times 1,000$ (cell) 크기의 공간에서 60 개의 $\mathrm{CPU}$ 로 모의실험한 결과를 그림 7에서 비교하였으며, 보는 바와 같이 세 경우 모두 일치함을 확 인하였다.

단일 프로세서로 모의실험을 한 결과와 60개의 CPU로 모의실험한 결과가 위의 실험에서와 같이 일치하다는 것 을 토대로 크기가 $4 \times 4 \times 4(\mathrm{~m})$ 이고, 두께가 $30 \mathrm{~cm}$ 인 콘크리 트 구조물의 외부에서 포인트 소스를 여기시키고, 콘크리 트 구조물의 가운데에서 $\mathrm{Ez}$ 값을 측정한 결과와 콘크리 트 구조물이 없는 자유공간의 가운데에서 $\mathrm{Ez}$ 값을 측정 하여 비교한 결과는 그림 8 과 같다.

콘크리트 구조물의 가운데에서 측정한 $\mathrm{Ez}$ 값의 크기가 


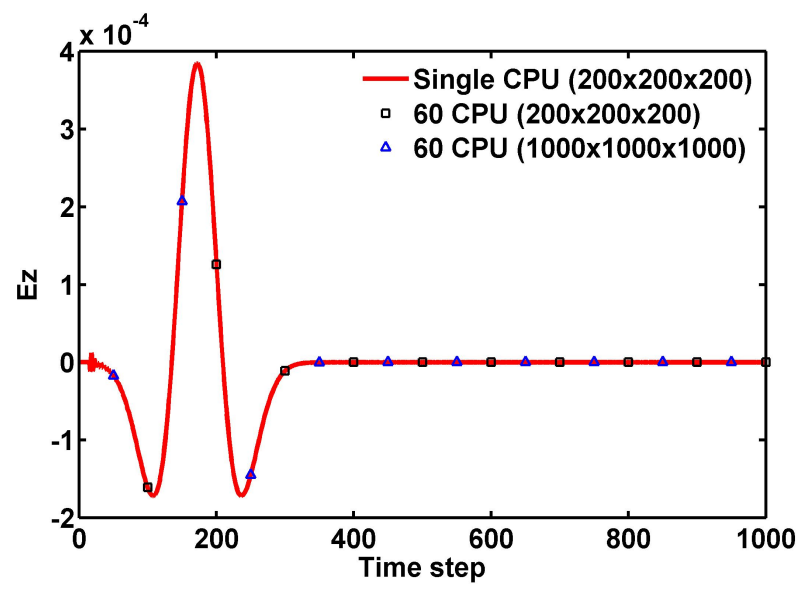

그림 7. 시뮬레이션에 따른 $\mathrm{Ez}$ 값 비교

Fig. 7. Comparison of Ez value for various simulations.

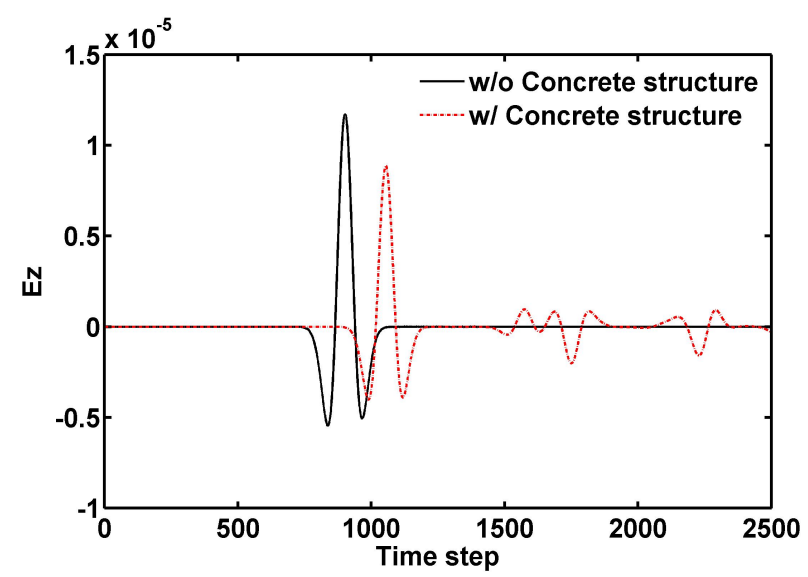

그림 8. 콘크리트 내부에서의 $\mathrm{Ez}$ 값 변화

Fig. 8. Ez value changes inside concrete structure.

콘크리트 구조물이 없는 자유공간의 가운데에서 측정한 $\mathrm{Ez}$ 값의 크기에 비하여 작아진 것을 확인할 수 있다. 이 를 통해 콘크리트 구조물 외부에서 여기된 포인트 소스 가 손실이 있는 물질인 콘크리트 구조물을 통과하며, 산 란과 감쇄되었다는 것을 알 수 있다. 또한, 포인트 소스가 콘크리트 구조물을 통과하며, 유전율의 영향을 받아 콘크 리트 구조물이 없는 자유공간에서 측정한 $\mathrm{Ez}$ 값에 비하 여 늦게 도착하는 것을 볼 수 있었으며, 콘크리트 구조물 내부의 공진현상 때문에 여러 리플이 따라오는 것을 확 인할 수 있다.

\section{$\mathrm{V}$. 결 론}

본 연구에서는 공간 분할 병렬처리를 위한 60 개의 $\mathrm{CPU}$ 로 이루어진 클러스터를 구축하였으며, 이를 기반으 로 MPI를 이용하여 병렬 FDTD 알고리즘을 구현하였다. 이를 이용하여 단일 $\mathrm{CPU}$ 환경일 때보다 더욱 빠르게 계 산을 수행할 수 있으며, 단일 프로세서 환경일 때보다 더 욱 큰 규모의 해석공간에 대한 해석이 가능하다. 향후에 는 인체, 항공기, 나노 플라즈모닉 구조 등 복잡하고 다양 한 구조에 대한 효율적인 광대역 전자파 해석을 수행할 예정이다.

\section{References}

[1] A. Taflove, S. C, Hagness, Computational Electrodynamics: The Finite-Difference Time-Domain Method, 3rd ed., Artech House, 2005.

[2] K. -Y. Jung, F. L. Teixeira, and R. M. Reano, "Au/SiO nanoring plamon waveguides at optical communication band", J. Lightw. Technol., vol. 25, no. 9, pp. 2757-2765, Sep. 2007.

[3] 하상규, 조제훈, 김형동, 최재훈, 정경영, "정확하고 효 율적인 인체 FDTD 분산 모델링", 한국전자파학회논 문지, 23(1), pp. 108-114, 2012년 1월.

[4] 주정명, 홍진영, 신상진, 김동현, 오이석, "콘크리트 벽 의 비파괴검사를 위한 초광대역 레이더의 2차원 FD$\mathrm{TD}$ 시뮬레이션에서 안테나 모델링의 영향", 한국전자 파학회논문지, 24(1), pp. 98-105, 2013년 1월.

[5] 현승엽, "동축 프로브 급전구조에 대한 FDTD 전원 모 델들의 상호 관계에 관한 비교 연구", 한국전자파학회 논문지, 25(1), pp. 114-122, 2014년 1월.

[6] C. Guiffaut, K. K. Mahdjoubi, "A parallel FDTD algorithm using the MPI library", IEEE Antennas Propag. Mag., vol. 43, no. 2, pp. 94-103, Apr. 2001.

[7] J. Wang, O. Fujiwara, S. Watanabe, and Y. Yamanaka, "Computation with a parallel FDTD system of humanbody effect on electromagnetic absorption for portable telephones", IEEE Trans. Microw. Theoy Technol., vol. 52, no. 1, pp. 53-58, Apr. 2004. 
[8] Y. Zhao, Y. Hao, "Full-wave parallel disperisve finite-difference time-domain modeling of three-dimensional electromagnetic cloaking structures", J. Comput. Phys., vol. 228, pp. 7300-7312, Jun. 2009.

\section{박 성 민}

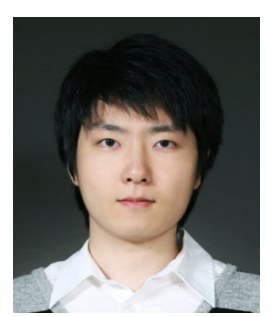

건물구조 해석
2011년 8월: 명지대학교 전자공학과 (공학 사)

2011년 3월 2012년 7월: 전자부품연구원 위촉연구원

2012년 9월 현재: 한양대학교 전자공학 과 석사과정

[주 관심분야] FDTD 모델링, 병렬FDTD,
[9] MPICH (MPI Chameleon), Argonne National Laboratory: http://www.mcs.anl.gov/

[10] 이홍석, 김정한, 이승우, 이석, "MPI 병렬 프로그래밍", 어드북스, 2010.

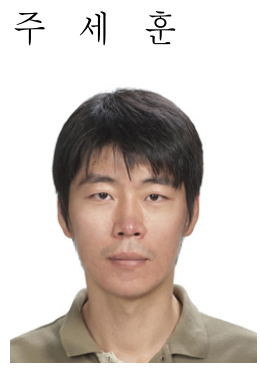

1997년 2월: 한양대학교 전파공학과 (공학 사)

1999년 2월: 한양대학교 전자통신전파공 학과 (공학석사)

1999년 3월 2000년 2월: 서울대학교 수 중음향특화연구센터 연구원

2003년 8월: 한양대학교 전자통신전파공 학과 (공학박사)

2003년 11월 현재: 한국전자통신연구원 부설연구소 책임연구 원

[주 관심분야] 초고주파 공학, 전자파 수치해석

박 윤 미

1991년 2월: 포항공과대학교 물리학과 (이 학사)

1993년 2월: 포항공과대학교 전자공학과 (공학석사)

1993년 3월 1997년 2월: 한국전자통신연 구원 연구원

2001년 8월: 한국과학기술원 전기전자공 학과 (공학박사)

2002년 12월 현재: 한국전자통신연구원 부설연구소 책임연구 원 실장

[주 관심분야] 고출력 전자기파, $\mathrm{RF}$ 필터, 배열안테나

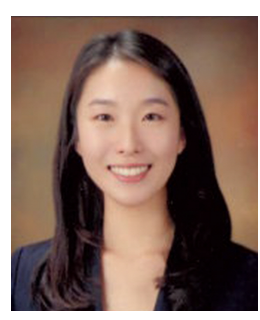

2004년 2월: 충남대학교 전자통신공학부 (공학사)

2010년 8월: 서울대학교 전기컴퓨터공학 부 (공학박사)

2010년 9월 2012년 4월: 삼성전자 무선 사업부 책임연구원

2012년 4월 현재: 한국전자통신연구원 부 설연구소 선임연구원

[주 관심분야] 전자파 수치해석, $\mathrm{EMI} / \mathrm{EMC}$, 고출력 전자기파 
THE JOURNAL OF KOREAN INSTITUTE OF ELECTROMAGNETIC ENGINEERING AND SCIENCE. vol. 25, no. 3, Mar. 2014.

\section{김 기 백}

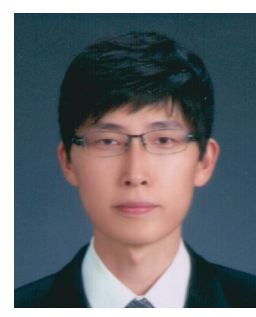

2010년 2월: 충남대학교 전파공학과 (공학 사)

2012년 2월: 충남대학교 전파공학과 (공학 석사)

2012년 4월 현재: 한국전자통신연구원 부 설연구소 연구원

[주 관심분야] 건물구조 해석, 안테나
정 경 영

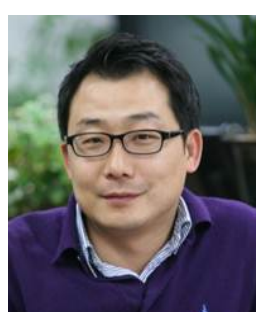

1996년: 한양대학교 전파공학과 (공학사) 1998년: 한양대학교 전자통신공학과 (공 학석사)

2008년: 미국 Ohio State University 전기 및 컴퓨터공학과 (공학박사)

1998년 2001년: 현대전자 전임연구원

2001년 2004년: 팬택앤큐리텔 선임연구원 2008년 2009년: 미국 Ohio State University 전기 및 컴퓨터공학

과 Post-Doctoral Researcher

2009년 2011년: 아주대학교 전자공학부 전임강사

2011년 현재: 한양대학교 융합전자공학부 조교수

[주 관심분야] 전자파 수치해석, 복잡물질 전자파모델링, 플라 즈모닉 구조, $\mathrm{HPEM}$, 초고주파공학 